\title{
Long term outcome and clinical experience on immune tolerance induction therapies in infantile Pompe disease
}

\author{
Stephanie Austin*, Priya Kishnani \\ From Proceedings of the 6th European Symposium: Steps Forward in Pompe Disease \\ Berlin, Germany. 23-24 November 2012
}

Pompe disease (glycogen storage disease type II) is an autosomal recessive lysosomal storage disorder caused by a deficiency of the enzyme acid alpha-glucosidase. Enzyme replacement therapy (ERT) with alglucosidase alfa has resulted in a clinical benefit in a subset of patients. Crossreactive Immunological Material (CRIM)-negative status is associated with poor prognosis. Patients with CRIM-negative infantile Pompe disease mount a strong immune response against alglucosidase alfa ERT, resulting in a clinical decline and death despite therapy. Most develop high sustained antibody titers. Based on our clinical and laboratory experience, about 40 percent of patients with infantile Pompe disease develop HSAT. Early identification of patients at risk is needed to allow for treatment intervention with immune tolerance induction (ITI) protocols. These protocols have included the use of agents such as rituximab, methotrexate, IVIG, and agents that target the plasma cells. Different treatment approaches are needed for patients with Pompe disease treated with ITI in the naïve setting as compared to patients with high sustained antibody titers. Without ITI, the CRIM-negative patients do poorly on ERT alone. We will present a successful global experience in 15 cases and discuss the safety, efficacy and feasibility of a clinical algorithm developed at our institution to identify CRIM-negative status and allow timely initiation of ERT and ITI in this vulnerable population. Our data show that the clinical algorithm of rapidly diagnosing and initiating ITI coincident with the start of ERT in CRIM-negative patients is feasible and can be achieved in a timely manner.

Published: 29 May 2013

Department of Pediatrics, Duke University Medical Center, Durham, North Carolina, USA

C Biomed Central

(0) 2013 Austin and Kishnani; licensee BioMed Central Ltd. This is an Open Access article distributed under the terms of the Creative Commons Attribution License (http://creativecommons.org/licenses/by/2.0), which permits unrestricted use, distribution, and reproduction in any medium, provided the original work is properly cited.
doi:10.1186/1471-2474-14-S2-08

Cite this article as: Austin and Kishnani: Long term outcome and clinical experience on immune tolerance induction therapies in infantile Pompe disease. BMC Musculoskeletal Disorders 2013 14(Suppl 2):08.

Submit your next manuscript to BioMed Central and take full advantage of:

- Convenient online submission

- Thorough peer review

- No space constraints or color figure charges

- Immediate publication on acceptance

- Inclusion in PubMed, CAS, Scopus and Google Scholar

- Research which is freely available for redistribution Submit your manuscript at
www.biomedcentral.com/submit C Biomed Central 